\title{
Integrated sectors - diversified earnings: the (missing) impact of offshoring on wages and wage convergence in the EU27
}

\author{
Aleksandra Parteka · Joanna Wolszczak-Derlacz
}

Received: 21 August 2013 / Accepted: 17 November 2014 / Published online: 30 January 2015

(C) The Author(s) 2015. This article is published with open access at Springerlink.com

\begin{abstract}
This paper assesses the impact of international outsourcing/offshoring practices on the process of wage equalization across manufacturing sectors in a sample of EU27 economies (1995-2009). We discriminate between heterogeneous wage effects on different skill categories of workers (low, medium and high skill). The main focus is on the labour market outcomes of vertical integration, so we augment a model of conditional wage convergence through the inclusion of sector-specific broad and narrow outsourcing/offshoring indices based on input-output data (World Input Output Database, April 2012 release). Twoway relations between trade and wages are addressed through the use of a gravity-based sector-level instrument. We find no evidence supporting unconditional skill-specific wage convergence in EU sectors. In a conditional setting, (slow) wage convergence takes place, but international outsourcing plays a negligible role in wage equalization. Moreover, even though regression results indicate that offshoring reduces the wage growth of domestic medium- and low-skilled workers, we show that this negative effect is economically small.
\end{abstract}

Keywords Wage $\cdot$ Convergence $\cdot$ International outsourcing $\cdot$ Offshoring · Input-output

The research has been conducted within the project financed by the National Science Centre (NCN), Poland (decision number DEC-2013/11/B/HS4/02134). Financial support from NCN is gratefully acknowledged. We also thank two anonymous referees, David Card, as well as the participants to conferences (Max Weber Conference - European University Institute, Warsaw International Economic Meeting, DEGIT, Macromodels) and seminars (Labor Lunch Seminar - University of California, Berkeley; Universita' Politecnica delle Marche, Ancona; Warsaw School of Economics, Gdansk University of Technology) for useful remarks on an earlier version of this paper. The usual disclaimers apply.

A. Parteka $(\bowtie) \cdot$ J. Wolszczak-Derlacz

Faculty of Management and Economics, Gdansk University of Technology,

Narutowicza 11/12, 80-233 Gdansk, Poland

e-mail: aparteka@zie.pg.gda.pl 


\section{Introduction}

Despite the ongoing process of integration and the hopes of less-developed EU members to catch up quickly with the living standards of Western European countries, wage differentials within the European Union are still very high. In 2011, average annual net earnings in the EU varied from around 1,698 euros in Bulgaria to almost 21,000 euros in Luxembourg (corresponding respectively to approximately 3,440 and 16,942 euros in PPS terms; data from Eurostat). Our data shows that in 2009 the wages of low-skilled workers in manufacturing (with only primary education) ranged from only $13 \%$ of the EU27 average in Bulgaria to $221 \%$ in Belgium. A similar wage disparity also affects better educated workers, for instance the high-skilled (tertiary education) wage ranged between $17 \%$ (Bulgaria) and $212 \%$ (Germany) of the EU27 average. The greatest wage dispersion is observed in traditional sectors - manufacturing, textiles, leather and footwear. ${ }^{1}$ Hence, from the welfare point of view it is clear that the wage convergence process in the EU has not yet come to an end and, given the EU cohesion target, the question is still of great policy relevance.

Looking at the labour demand side, wages and salaries are the principal component of the total expenditures borne by European employers for the purpose of employing staff (ranging from $66 \%$ in Belgium to $87 \%$ in Denmark - data refer to 2011; source: Eurostat). Wage differentials, combined with a high degree of market and political integration between the 'old' and 'new' member states have stimulated new channels of international outsourcing/offshoring ${ }^{2}$ across Europe (Baldone et al. 2001; Egger 2006; Egger and Egger 2002; Marin 2006), exactly in the same way as elsewhere in the world (Feenstra 2010). We document that offshoring in EU27 manufacturing rose from $26 \%$ of value added in 1995 to $42 \%$ in $2008,{ }^{3}$ when the effects of the international economic crisis were about to appear.

Most of the related literature focuses on the consequences of the cross-border disintegration of the production process for wage differentials across skill groups (skilled/unskilled wage ratio, wage bill; see, among others, Feenstra and Hanson 1996, 2001; Acemoglu and Autor 2011; Egger and Stehrer 2003). However, this paper takes a different focus: we ask how offshoring trends affect the diversity of the sectoral earnings of a given skill group across European countries. Consequently, the main aim of this paper is to assess the impact of international outsourcing practices on the process of wage equalization across EU sectors - we focus on the impact of offshoring on the conditional wage convergence mechanism.

Economic theory offers alternative views on the international fragmentation-wages nexus. The traditional explanation (factor price equalisation theorem, FPE, stemming from the Hecksher-Ohlin framework and considering the effects of the exogenous shift from no

\footnotetext{
${ }^{1}$ The data refer to the average sectoral labour remuneration per hour worked (authors' calculations with data from WIOD, 2012). EU27 is used throughout the paper as the period analysed covers the years before further EU enlargements. Additionally, Magda et al. (2011) provide micro-based evidence on the existence of substantial differences in earnings across sectors in Eastern European countries compared to the Western European states analyzed, even when controlling for a wide range of employee, job and employer characteristics.

${ }^{2}$ In the literature, several names (outsourcing, de-localization, fragmentation, vertical specialization, slicing the value chain, production sharing) have been used to describe the increasing importance of the "geographic separation of activities involved in producing a good (or service) across two or more countries" (Feenstra and Hanson 2001, p.1). We use the terms 'international outsourcing' and 'offshoring' interchangeably.

${ }^{3}$ Broad offshoring with respect to the value added of the domestic sector (2), weighted average across 13 manufacturing sectors listed in Table 2A in the full version of the paper including appendix (Parteka, Wolszczak-Derlacz 2014); authors' calculations with data from WIOD 2012.
} 
trade to free trade in goods) suggests that free trade leads to an equality of the prices of inputs, such as wages. The EU can undoubtedly be considered a set of integrated economies with barriers to trade largely eliminated, but with cross-country wage differentials still present (see also Magda et al. 2011 and Fig. 1 in Section 2). In the presence of international fragmentation of production, we are likely to see changes in relative labour demand (Hijzen and Swaim 2007) concerning those workers' whose jobs are subject to offshoring. If FPE is at play, an upward push on the wages of this group should be observed in countries where they are typically lower (e.g. Eastern Europe) and which serve as outsourcing destinations for higher wage countries (e.g. more advanced Western European economies), where the opposite result should be observed. This mechanism should lead to cross-country wage convergence.

However, ambiguous effects of trade in parts and components on wages and on factor price equalisation mechanism are present in a large number of models. Already in the 1990s, Jones and Kierzkowski $(1990,1998)$ showed that offshoring can be thought of as technological progress ${ }^{4}$ with very complex effects and the possibility of an 'anti-StolperSamuelson effect'. The possibility of non-factor price equalisation and factor convergence or divergence is present in many models of offshoring, e.g. those by Deardorff (2001), Venables (1999), Kohler (2004), Markusen (2005) and Grossman and Rossi-Hansberg (2008). Offshoring need not produce obvious winners and losers (typically perceived to be low-skilled labourers in the West hurt by trade with less developed countries - as argued by Wood, 1995 and others). ${ }^{5}$ In particular, recent theoretical models view offshoring as trade in tasks (among others, Grossman and Rossi-Hansberg 2008, 2012; Baldwin and RobertNicoud 2014), producing somewhat complex effects on the wages of workers of differing (skill) type, especially the low-skilled. ${ }^{6}$ Productivity gains stemming from offshoring may actually generate an increase in domestic wages (see Michel and Rycx 2014). In sum, it is evident that, according to alternative models and their underlying assumptions, offshoring can either decrease or increase domestic wages and, given this theoretical ambiguity, the problem of international wage equalization is instead an empirical question to be answered with the use of real data. This is what we do in this paper.

The theoretical basis of our analysis draws on the canonical model of wage differentials across skills (Acemoglu and Autor 2011) combined with the literature incorporating heterogeneous workers into models of international trade and the global integration of value

\footnotetext{
${ }^{4}$ Acemoglu et al. (2012) introduce directed technological change into a Ricardian model of offshoring and show that offshoring and technical change are substitutes in the short run but complements in the long run. Consequently, unskilled labour can either see their wages rise or fall.

${ }^{5}$ Along these lines, in a widely-cited paper Feenstra and Hanson (1999) argue that outsourcing significantly lowers the cost share of production labour in the US. Interesting micro-level evidence on low-skill workers losing, in terms of wages, as a result of outsourcing is provided in a study on Germany by Geishecker and Görg (2008). They find that a $1 \%$ increase in outsourcing reduces the wage in the lowest skill category by up to $1.5 \%$ (high-skill wages rise). Similarly, Hummels et al. (2011) in a Denmark-specific micro-level study find that offshoring tends to decrease the low skilled-wage (by 1.6\%) and increase the high-skilled wage (by $3.6 \%)$.

${ }^{6}$ Grossman and Rossi-Hansberg (2008) show that 'the effect of offshoring on low-skill wages depends on interplay between the 'productivity effect,' the 'relative price effect,' and the 'labour supply effect'. The final outcome concerning low-skill workers in the 'West' in particular is ambiguous and depends on the intensity of offshoring. A similar effect is found by Acemoglu et al. (2012). Productivity gains stemming from offshoring may actually generate an increase in domestic wages (see also Michel and Rycx 2014). On the other hand, Baldwin and Robert-Nicoud (2014) demonstrate in their 'integrating framework' that trade in tasks is similar to shadow migration and technical change and, importantly, it is possible to develop task-trade analogues of the FPE.
} 
chains (surveyed in Grossman 2013). In the empirical part of this paper, we extend a traditional estimation of the wage convergence equation performed with aggregate earnings, and consider wage patterns by skill category. Therefore, our paper is naturally strongly linked to the empirical literature on real convergence. The paper follows on from the huge wave of research on this topic in the 1980s and 1990s, ${ }^{7}$ the focus of which was mainly on the cross-country convergence of income per capita (or productivity) levels, with the "iron-law" beta convergence rate being found to be approximately. $2 \%$ per year (see the discussion on the current state of the debate in Barro (2012). The general conclusion is that the process of convergence is far from automatic: it is conditional on the characteristics, policies and institutional settings of specific countries. Global differences between developed and developing countries, despite rapid growth episodes in some parts of the world (China, India), are likely to continue (Rodrik 2011). Additionally, in Europe 'club convergence' can still be an issue (Bartkowska and Riedl 2012).

The literature on wage convergence mechanisms is much scarcer. In the specific case of Europe, which is our main interest, ${ }^{8}$ it seems that despite a documented rise in offshoring practices (Baldone et al. 2001; Marin 2006; Schwörer 2013), the link between this and a cross-border wage convergence mechanism has not been fully explored. In the past, studies of the EU15 economies (or subsamples of them) focused mainly on the effects of the common market, trade integration and the common currency on factor price equalization and did not reach a common conclusion in terms of wage/labour cost convergence (Tovias 1982; Andersen et al. 2000; Mora et al. 2005 - see the survey in Ramskogler 2010, 2012, who documents the state of wage convergence in the EMU and the role of Germany as a transnational wage leader). Very few studies take into account the New Member States and industry-specific wage developments.

Our analysis is closer to those few existing contributions, which however are limited in their country coverage and/or time span, on the wage equalization observed in the enlarged EU context at the industry level. ${ }^{9}$ Egger (2006) draws on data on real monthly wages in 14 NACE 2-digit manufacturing industries and concludes that outsourcing fosters the sigma convergence of industry-specific wages and limits cross-country differences at the industry level. Egger and Pfaffermayr (2004) reject a hypothesis of unconditional beta wage convergence both within the EU and in five central and eastern European countries (CEECs) in the years 1993-2000, but support the hypothesis of international (cross-country) factor price equalization as a result of outsourcing practices.

To the best of our knowledge, there is no up-to-date sector-level study that takes into account a wide set of both old and new EU member states and simultaneously analyses the effects of international outsourcing on wage convergence patterns considering different skill groups of workers. Hence, we contribute to the existing literature in several ways. First of all, this is likely to be the first study to examine the effect of offshoring on sectoral earnings in such a wide sample of EU countries over a time span long enough to capture the effects of east-west integration from the European Agreements to the economic crisis (from 2008).

\footnotetext{
${ }^{7}$ The most-cited works include (among others): Baumol (1986), De Long (1988), Barro (1991), Barro et al. (1991), Barro and Sala-i-Martin (1992).

${ }^{8}$ Given the scope of our paper, we leave aside the literature on price convergence (Wolszczak-Derlacz 2010).

${ }^{9}$ In general, most studies on transition economies focus on aspects loosely related to our research, e.g. the effects of foreign direct investment and trade on wages (Egger and Egger 2002; Onaran and Stockhammer, 2008; Polgár and Wörz 2010) or the wage-bill and skill premiums (Egger and Stehrer 2003; Esposito and Stehrer 2009).
} 
Our empirical analysis is based on a sector-level database which links trade and labour market data for 13 manufacturing sectors for all the EU27 economies (both old and new member states) for the years 1995-2009. Second, we discriminate between heterogeneous responses of different skill categories of workers (low, medium and high skill). ${ }^{10}$

The main focus is on the labour market outcomes of vertical integration (offshoring), so we augment a dynamic model of unconditional wage convergence by including sectorspecific offshoring indices. An important contribution is the fact that by using recent international input-output statistics (WIOD - World Input Output Database, release April 2012) we are able to construct precise sector-level measures of outsourcing (broad and narrow) for both the EU15 and the new member states. Additionally, we compare the effects of international outsourcing (offshoring) with national outsourcing. Finally, two-way relations between trade and wages and the resulting endogeneity issues are addressed by means of a GMM system estimator and the use of a gravity-based sectorlevel instrument for offshoring indices. Our basic results are supported by a set of robustness checks.

The rest of the paper is structured as follows. In Section 2, we present the data and some descriptive statistics on the wage differentials and outsourcing patterns emerging in our sample. In Section 3, we present a simple theoretical framework of the model and its empirical specification (a dynamic model of sector-level wage convergence). Next, in Section 4, we provide the results of the estimations, revealing the effects of outsourcing on the evolution of the wage conditions of workers with various skill levels. Finally, Section 5 concludes.

\section{Empirical setting}

\subsection{Data and measurement}

Specifically for the purposes of this study we construct a sector-level database matching labour market data with outsourcing and offshoring measures at the level of single sectors observed in the years 1995-2009. Our analysis takes into account 27 EU countries (Table 1A in the Appendix) and 13 manufacturing sectors (Table 2A in the Appendix). ${ }^{11}$

We draw mainly on industry-specific data that has been recently made available from The World Input Output Database (WIOD April 2012 release which is a substantial extension of the EU KLEMS database, see Timmer et al. 2012 for an overview; we also take into account the March 2013 update). This provides a set of harmonized supply and use tables, alongside data on international trade in goods and services, integrated into sets of intercountry input-output tables (see Dietzenbacher et al. 2013) which can be matched with socio-economic indicators. We use WIOD's Socio-Economic Accounts to obtain statistics

\footnotetext{
${ }^{10} \mathrm{An}$ increasing number of papers document the phenomenon of job polarisation due to so-called 'routinization' (among others: Goos et al. 2009, Acemoglu and Autor 2011), so the losers' group is likely to include workers performing manual or routine tasks, independently of their educational background. Unfortunately, our data does not allow us to distinguish between tasks performed by different skill groups of workers.

${ }^{11}$ The Appendix is available in the full version of the paper (Parteka, Wolszczak-Derlacz 2014). Theoretically, WIOD provides data for 35 industries. We concentrate on the manufacturing sectors, excluding services (where several of the statistics are based on extrapolations and are very noisy) and the sector "Coke, Refined Petroleum And Nuclear Fuel" (code 23) which is highly dependent on resource abundance and is an outlier (in terms of very low levels of value added which for some of the countries leads to extremely high outsourcing intensity).
} 
on labour remuneration and hours worked to calculate the wages per hour of different categories of workers. WIOD provides data for three groups (high-, medium- and low-skill labour). ${ }^{12}$

For some countries, nominal variables are originally expressed in national currencies. Thus we use the bilateral exchange rates from the Penn World Table (PWT 7.1) to put all wages into dollars, and the CPI from the World Bank to report all nominal values in constant terms $(2009=100)$. In addition, we also calculate wages expressed in purchasing power (using PPP indices from PWT 7.1).

The construction of precise measures of offshoring was possible with the use of the World Input-Output Tables - WIOT (which are a part of WIOD; see Dietzenbacher et al. 2013 for an application). We adopt the division into narrow and broad international outsourcing (Feenstra and Hanson 1999) and compute the measures based on the input-output tables by following the definitions in Hijzen and Swaim (2007). ${ }^{13}$ Intraindustry offshoring ('narrow' international outsourcing) measures the share of imported intermediate inputs from the same industry in terms of industry added value. Formally, narrow offshoring for sector $j$ (we suppress the country and time subscripts for simplicity) is computed as: ${ }^{14}$

$$
\operatorname{Int} O U T_{j}^{N}=\frac{I_{k=j}}{V A_{j}}
$$

where $I$ refers to imported intermediate purchases from foreign industry $k=j$ by domestic industry $j$ and $V A$ denotes the value added. Inter-industry offshoring ('broad' international outsourcing) is given by the ratio of imported intermediate purchases by industry $j$ from all industries $k$ other than $j$ to the added value:

$$
\operatorname{Int} O U T_{j}^{B}=\frac{\sum_{k=1}^{K} I_{k \neq j}}{V A_{j}} \text {. }
$$

\footnotetext{
${ }^{12}$ Skills are defined here on the basis of educational attainment. High skill corresponds to academic education, medium skill to upper secondary education and low skill to primary education. The skill-sector specific wages per hour are constructed on the base of data on gross labour compensation (including salaries paid directly to employees and costs of employing labour which are incurred by the employer e.g. taxes, contribution to compulsory social insurance), the share of labour compensation obtained by workers with given skills, the total number of hours worked by all persons engaged in a given sector and the share of hours worked by workers of a given category. Detailed information on country specific data sources and methods to obtain labour compensation can be found at: http://www.euklems.net and www.wiod.org.

${ }^{13}$ Narrow outsourcing corresponds to the diagonal in import-use matrix. As argued in Hijzen et al. (2007) it is perceived to approximate best the notion of fragmentation within the industry/sector and is particularly appropriate at relatively high levels of aggregation. However, the narrow measure has its disadvantages, eg. it is highly dependent on the way industries/sectors are defined (classified). Broad outsourcing overcomes this limit as it takes into account intermediates coming from other industries/sectors. Additionally, the distinction between the two types of outsourcing measures allows us to disentangle intra-industry and inter-industry outsourcing effects on industries' performance (which need not be the same - as in Hijzen et al. 2007).

${ }^{14} \mathrm{We}$ are aware that the use of 'imported intermediate inputs' to construct outsourcing proxy is not perfect as the data collection often assumes so-called 'import comparability' or 'proportionality assumption' (see Feenstra and Jensen 2012). The caveats of indirect offshoring measures are also discussed in Michel and Ryck (2012). Consequently our results account for the effects of effective offshoring only, as registered in input-output data.
} 

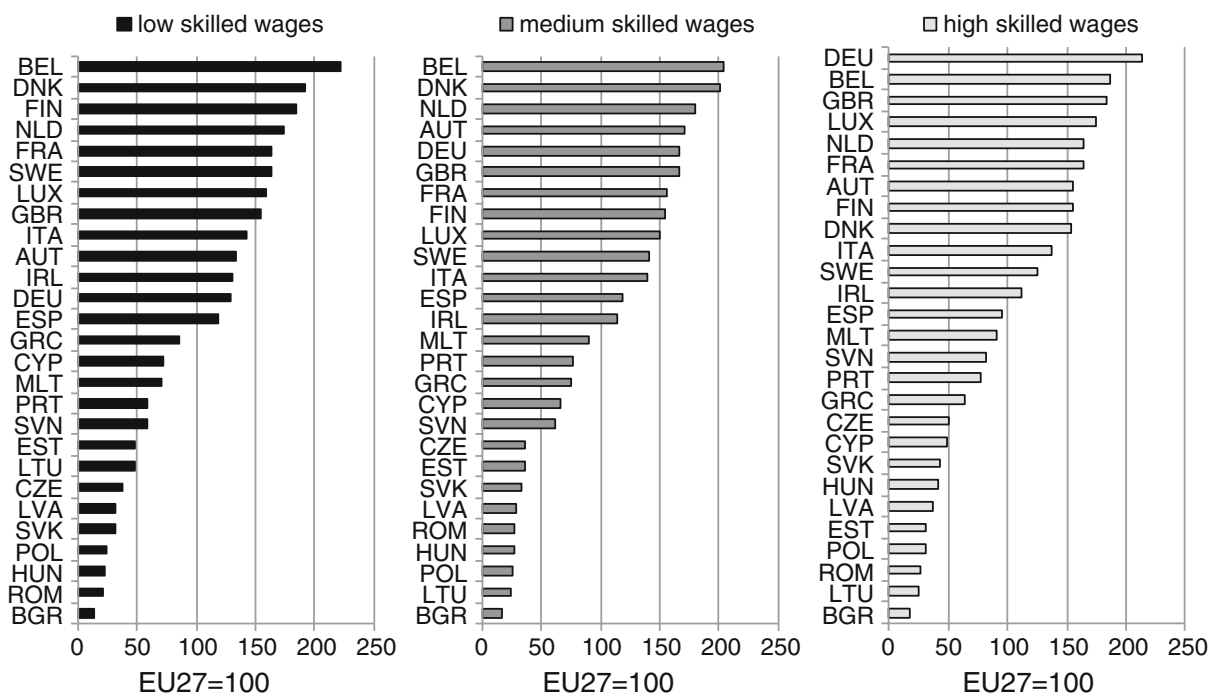

Fig. 1 Cross-country differences in average wages in manufacturing sectors, by skill type, EU27=100, 2009. Note: Weighted averages across 13 manufacturing sectors in single EU27 countries; weights correspond to sector size (employment). Source: own elaboration with socioeconomic accounts data from WIOD 2012

In both cases (1) and (2) we consider imported intermediates from the whole world (global offshoring). ${ }^{15}$

Additionally, for comparison, by using national input-output tables we compute analogous measures of domestic narrow and broad outsourcing (DomOUT $T_{j}^{N}$ and DomOUT ${ }_{j}^{B}$ respectively). These consider only inputs coming from and used in home sectors (and thus account for flows of intermediates within one country).

In order to build gravity-based instrument for trade variables (described below) we draw on bilateral sector-level trade data from the WIOD combined with gravity variables from the CEPII. ${ }^{16}$

\subsection{Descriptive evidence on wage and outsourcing patterns in EU27 countries}

Figure 1 illustrates the presence of huge wage differentials in manufacturing across the EU27 countries, which are typical for all skill categories in the labour force. For instance, the typical hourly wage of low-skilled workers in 2009 (the last year for which we have the data) ranged between only $13 \%$ of the EU27 average in Bulgaria to $221 \%$ in Belgium.

\footnotetext{
${ }^{15}$ The World Input-Output Tables (WIOT) provide separate data on the supply of intermediates imported from 40 countries and the rest of the world (RoW), so we are able to account for global offshoring practices. These 40 countries encompass the $27 \mathrm{EU}$ countries, Australia, Brazil, Canada, China, India, Indonesia, Japan, Korea, Mexico, Russia, Taiwan, Turkey and the US). A restriction to European offshoring (encompassing imports of intermediates from manufacturing sectors located in EU27 countries or in NMS12 only) is provided in one of our robustness checks.

${ }^{16}$ The CEPII provides the data for the period 1948-2006. We have updated the series concerning time-varying variables (eg. common currency or trade agreements) for the years 2007-2009. See Head and Mayer (2015) for the details on the gravity procedure and Santos Silva and Tenreyro (2006) for a discussion of alternative estimators in the gravity equation estimation.
} 


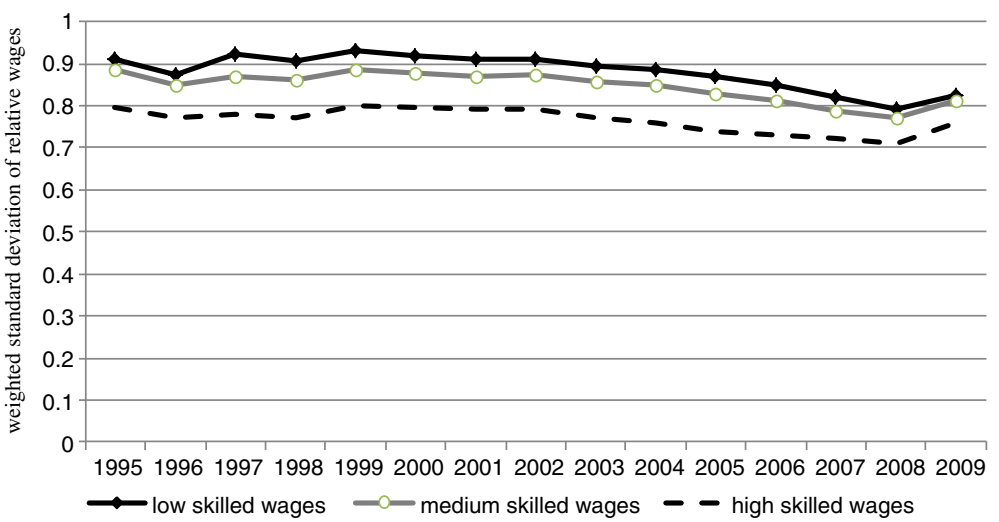

Fig. 2 Dispersion of relative wages (EU27=100) across manufacturing sectors in EU27 countries, by skill type, 1995-2009. Note: Weighted standard deviation of relative wages across EU27 countries and 13 manufacturing sectors; weights correspond to sector size (employment). Source: own elaboration with socioeconomic accounts data from WIOD 2012

These huge wage differentials not only concern the low skilled; they are typical also for medium- and high-skill workers. Unsurprisingly, wages are highest in rich Western European economies such as Germany, Benelux or the Scandinavian countries, while they are the lowest in new member states from Central and Eastern Europe.

In terms of the degree of wage inequality within each skill group category, the variation in wages in the EU27 is the highest in the case of workers with only primary education and the lowest in the case of those with completed tertiary education (Fig. 2). In terms of

inequality of low skilled wages

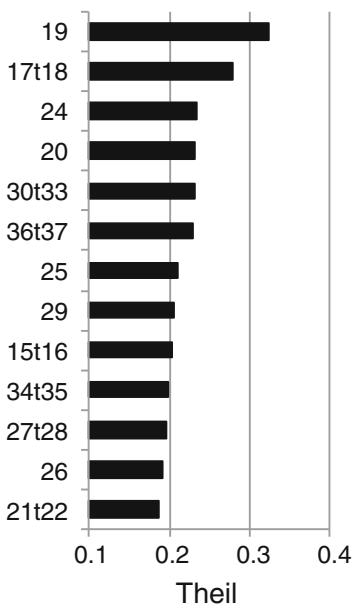

$\square$ inequality of medium skilled wages

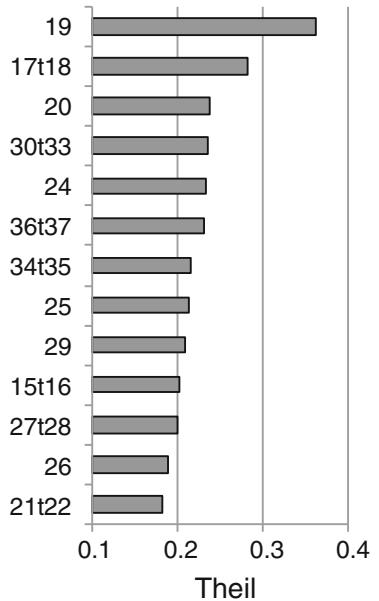

$\square$ inequality of high skilled wages

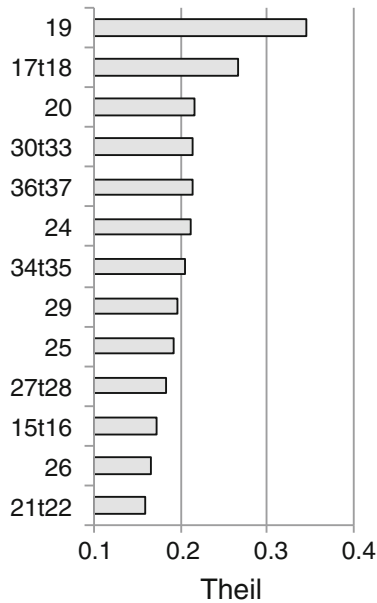

Fig. 3 Inequality of relative wages (EU27=100) within manufacturing sectors across EU27 countries, by skill type, 2009. Note: Weights correspond to sector size (employment). Codes: Sectors as in Table 2A in Appendix (Parteka, Wolszczak-Derlacz 2014) Source: own elaboration with socioeconomic accounts data from WIOD 2012 


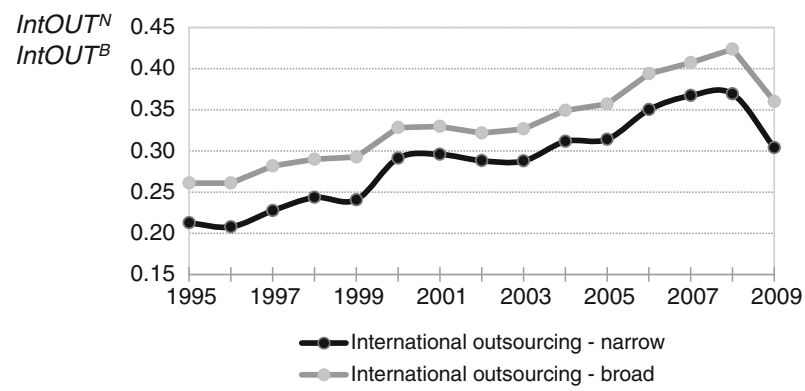

Fig. 4 Trends in offshoring in manufacturing, EU27, 1995-2009. Note: International outsourcing (offshoring) measured as a ratio of globally imported intermediate inputs to the value added (exact formulas in the text). Weighted averages across 13 manufacturing sectors in single EU27 countries; weights correspond to sector size (employment). Source: own elaboration with input-output data from WIOD 2012

evolution over time, the changes are relatively negligible (a slight decrease in the standard deviation of wages took place between 2003 and 2008).

We further investigate the manufacturing sector in which the disparity of earnings is the highest. It turns out (Fig. 3) that the greatest degree of wage inequality across the EU27 is to be found in traditional sectors such as the manufacturing of leather and footwear or textiles. This pattern is common for all skill types.

Hence, the picture that emerges from these descriptive statistics proves the presence of significant and somewhat persistent wage differentials in EU27 manufacturing. We are interested in seeing if wage patterns are in any way influenced by fragmentation of the production process. Indeed, in the period of analysis offshoring practices (Fig. 4) increased substantially: when measured in the broad sense (2), the ratio of globally imported intermediate inputs to the value added rose from $26 \%$ in 1995 to $42 \%$ in 2008 (subsequently a drop was registered due to the global crisis). Figures for narrow offshoring (1) are slightly lower (21\% in 1995 to $37 \%$ in 2009). In the case of domestic outsourcing (Fig. 5), narrow outsourcing was fairly constant and there was a rise only in broad domestic outsourcing practices.

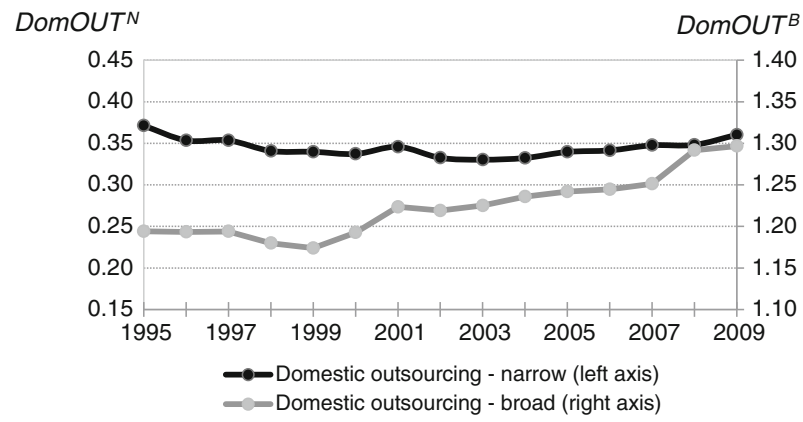

Fig. 5 Trends in domestic outsourcing in manufacturing, EU27, 1995-2009. Note: Domestic outsourcing measured as a ratio of domestically outsourced intermediate inputs to the value added (exact formulas in the text). Weighted averages across 13 manufacturing sectors in single EU27 countries; weights correspond to sector size (employment). Source: own elaboration with input-output data from WIOD 2012 


\section{Skill-specific wage convergence model}

\subsection{Theoretical framework}

In order to provide a theoretical framework for the empirical convergence analysis of wage patterns in the presence of worker heterogeneity, we first derive an analytical expression which defines the main determinants of the wages of different skill groups. We will consider the 'Ricardian model' of the labour market (Acemoglu and Autor 2011, pp. 45-83), which is an extension of the 'canonical model' used in the labour economics literature and which allows for trade in tasks, as in the recent theories of offshoring reviewed in the introduction. Such an approach emphasizes the role of technologies replacing tasks previously performed by labour and the similar role played by offshoring. As factors of production, there are three types of labour - high- $(h)$, medium- $(m)$ and low-skilled $(l)$ workers (with inelastic labour supplies $L a b_{h}, L a b_{m}$ and $L a b_{l}$, respectively) - and capital/technology embedded in machines $(K)$. The allocation of skills to tasks is such that workers of the same skill level can perform different tasks, but in equilibrium they receive the same wage ("law of one price"). Wage levels can be obtained as the values of marginal products of different types of skills (for an exact exposition, see Acemoglu and Autor 2011, p. 50), and consequently we can express the wages of different skill groups as functions of their productivity $(A)$, the labour supply $(L a b)$ and a task allocation term $(I):{ }^{17} W_{h}=f\left(A_{h}, L a b_{h}, I_{h}\right)$, $W_{m}=f\left(A_{m}, L a b_{m}, I_{h}, I_{l}\right), W_{l}=f\left(A_{l}, L a b_{l}, I_{l}\right)$. Importantly, this framework allows us to analyze the wage implications of international outsourcing practices, "offshoring" tasks to countries where they can be performed at lower cost, which is modelled through changes in the thresholds $\left[I_{l}, I_{h}\right]$, which are a function of outsourcing opportunities: $I_{s}=f(O U T)$, $s=\{h, m, l\} .^{18}$

In sum, in the light of task-based theory, labour supply $\left(L a b_{s}\right)$, technological change (capital/machines replacing skills, $K$ ) and trading opportunities (outsourcing intensity OUT) will affect wages. These implications guide the choice of the basic factors to be considered in the sector-level and skill-specific model of wage determination to be estimated. ${ }^{19}$ Consequently, concerning the domestic sector, we can express the wages of different categories of workers as a function:

$$
W_{s j t}=f\left(K_{j t}, L A B_{s j t}, O U T_{j t}\right), s=\{h, m, l\},
$$

and similarly in the foreign $(*)$ sector:

$$
W_{s j t}^{*}=f\left(K_{j t}^{*}, L A B_{s j t}^{*}, O U T_{j t}^{*}\right), s=\{h, m, l\},
$$

where $s=\{h, m, l\}$ refers to the skill type, $j$ denotes sector and $t$ time (country subscripts are omitted), $K$ denotes the capital to labour ratio, $L A B_{s}$ measures the abundance of each

\footnotetext{
${ }^{17}$ All tasks $i<I_{l}$ are performed by low-skilled workers, $i>I_{h}$ are performed by high-skilled workers and intermediate tasks are performed by middle-skilled workers $\left(0<I_{l}<I_{h}>1\right)$

${ }^{18}$ For instance, if the tasks in the range $\left[I^{\prime}, I^{\prime \prime}\right] \subset\left[I_{l}, I_{h}\right]$ are now offshored, then high-skilled workers are likely to benefit at the expense of medium- and low-skilled ones.

${ }^{19}$ Not all the terms are directly observable, i.e. the absence of direct information on $A_{h}, A_{m}, A_{l}$ can be an obstacle, but they are all sector-specific and thus indirectly depend on K. Additionally, following Acemoglu and Autor 2011 and Tinbergen's hypothesis we assume a log-linear increase in the demand for skills over time coming from technology, which will be captured by the introduction of appropriate dummies into the model.
} 
type of workers and $O U T$ indicates outsourcing intensity and captures the proportion of tasks performed abroad. ${ }^{20}$

Combining Eqs. 3 and 4 into a relative wage, we get the expression for the sector-level domestic/foreign $(*)$ wage differential:

$$
\frac{W_{s i j t}}{W_{s j t}^{*}}=f\left(\frac{K_{j t}}{K_{j t}^{*}}, \frac{L A B_{s j t}}{L A B_{s j t}^{*}} \frac{O U T_{j t}}{O U T_{j t}^{*}}\right), s=\{h, m, l\}
$$

\subsection{Empirical specification of the wage convergence model}

Being particularly interested in sector-level wage differentials across EU countries, we calculate relative hourly wages with respect to the EU27 average value (so that * in Eq. 5 corresponds to EU27). Thus for each country $i$, sector $j$, time period $t$ and skill category $s$,relative wages are expressed as the ratio:

$$
w_{s i j t}=\frac{W_{s i j t}}{W_{s j t}^{E U 27}}, s=\{h, m, l\} .
$$

The real hourly wages are calculated as labour remuneration divided by hours worked, deflated with the CPI and converted to 2009 USD. ${ }^{21}$

The real convergence literature (Barro and Sala-i-Martin 2004) provides a basic framework where the growth rates of the variable of interest (here: relative wages) are related to their past realizations and, if beta convergence takes place, the growth rate of the dependent variable is negatively related to its lagged levels. In order to test the absolute convergence hypothesis, the following regression is estimated:

$$
\Delta \ln w_{s i j t}=\alpha+\beta \ln w_{s i j t-1}+u_{i j t}, s=\{h, m, l\},
$$

where $\Delta \ln w_{s i j t}$ is the first difference of the log wage differential defined in Eq. 6 and approximates wage growth. The estimated coefficient of the lagged wage differential $(\beta)$ is the indicator of the convergence process. The speed of convergence is calculated as $\lambda=-\ln (1+\beta)$ and its 'half-life,' which indicates the period needed for half of the dispersion to disappear, according to the formula: $t_{1 / 2}=\frac{\ln (0.5)}{\ln (1+\beta)} \cdot 22$

Combining (7) with the subtraction of log-linearized versions of Eqs. 3 and 4 yields an augmented empirical model of relative (vis-à-vis the EU27 average) wage convergence to be estimated with sector-level data:

$$
\begin{aligned}
\Delta \ln w_{s i j t} & =\alpha+\beta \ln w_{s i j t-1}+\gamma_{1} \ln k_{i j t}+\gamma_{2} \ln l a b_{s i j t}+\gamma_{3} \ln o u t_{i j t}+D_{i j}+D_{t}+\varepsilon_{s i j t}, \\
s & =\{h, m, l\}
\end{aligned}
$$

\footnotetext{
${ }^{20}$ We are aware that wages are highly likely to be higher in sectors with higher productivity but this cannot be introduced directly into the empirical model as it is collinear with the capital to labour ratio. The correlation coefficient between value added per hour worked and $K$ equals 0.77 .

${ }^{21}$ To calculate real hourly wages in one common currency we follow the procedure used by the OECD: first deflating the series with CPI $(2009=100)$, and then converting into a common currency using the USD exchange rate from 2009. Alternatively, PPI could be used.

${ }^{22}$ Equation 7 can clearly be rewritten in terms of the wage levels: $\ln w_{s i j t}=\alpha+(1+\beta) \ln _{s i j t-1}+u_{i j t}$ which will be useful in the interpretation of the results and the assessment of their economic significance (Section 4.2.3)
} 
where $i$ denotes home country, $j$ refers to sector, $t$ to time period, $s$ denotes skill group. Variable $k$ refers to the capital to labour ratio, lab is the total number of hours worked by person engaged and out refers to the whole set of domestic and international outsourcing measures $\left(\right.$ DomOUT $^{\mathrm{N}}$, DomOUT $\left.^{\mathrm{B}}, \operatorname{IntOUT}^{\mathrm{N}}, \operatorname{IntOUT}^{\mathrm{B}}\right)$ described in Section 2.1. The small letters indicate that all the variables are expressed in relation to the EU27 average (log differences), analogously to Eq. 6.

Finally, we also consider an augmented specification with an interaction term between offshoring and lagged wages:

$$
\begin{aligned}
\Delta \ln w_{s i j t}=\alpha & +\beta \ln w_{s i j t-1}+\gamma_{1} \ln k_{i j t}+\gamma_{2} \ln l a b_{s i j t}+\gamma_{3} \ln o u t_{i j t} \\
& +\gamma_{4} \ln o u t_{i j t} \times \ln w_{s i j t-1}+D_{i j}+D_{t}+\varepsilon_{s i j t}, s=\{h, m, l\}
\end{aligned}
$$

In Eq. 9 the impact of offshoring on wages is assessed in two ways: by estimating its longterm impact on the growth of wage differentials $\left(\gamma_{3}\right),{ }^{23}$ i.e. the influence of offshoring on the steady states; and by analysing the coefficient of the interaction term $\left(\gamma_{4}\right)$, which measures the effect of offshoring intensity on the persistence parameter - the speed of convergence. $^{24}$

\section{Results}

\subsection{Unconditional vs conditional wage convergence - prima facie evidence}

Given that wage differentials in EU27 manufacturing seem to be very persistent (Section 2.2), the next step is to verify whether the process of wage convergence takes place. In Fig. 6 we show a comparison between a graphical representation of absolute (unconditional) wage convergence (dashed lines) and partial residuals plots (solid lines) showing the relationship between the independent variable of the convergence model (here: lagged wage levels) and the response variable (here: wage growth), given that other independent variables are also taken into account. As additional covariates, we consider factors present in model (8): the relative capital to labour ratio, the relative supply of each type of labour and (as our main interest is the impact of offshoring practices on wages) the international outsourcing intensity. ${ }^{25}$ If absolute wage convergence takes place, then we should obtain a negative relationship between the growth of wages and their lagged levels, corresponding to model (7).

\footnotetext{
${ }^{23}$ The parameter $\gamma_{3}$ in Eqs. 8 and 9 is obtained as the first partial derivative of $\Delta w_{i j t}$ with respect to out $t_{i j t}$ : $\partial \Delta w_{s i j t} / \partial o u t_{i j t}$.

${ }^{24}$ The formal interpretation of $\gamma_{4}$ in Eq. 9 is the following: it is the second partial derivative of $\Delta w_{i j t}$ with respect to out $t_{i j t}$ and $w_{i j t-1}: \partial^{2} \Delta w_{s i j t} / \partial o u t_{i j t} \partial w_{i j t-1}$ so that the speed of convergence is calculated now as $\lambda=-\ln \left(1+\beta+\gamma_{4} \times \overline{\text { out }_{i j}}\right)$.

${ }^{25}$ Here we employ the broad measure of offshoring $\left(\right.$ Int $\left.O U T^{B}\right)$. However, the figures are very similar when the narrow one $\left(\right.$ Int $\left.O U T^{N}\right)$ is used and when we consider domestic outsourcing.
} 
Fig. 6 Comparison of absolute (unconditional) and conditional wage convergence patterns, by skill group (manufacturing sectors, EU27, 1995-2009).

Note: the dashed line corresponds to model (7); the solid line refers to partial residuals obtained with model (8) with additional covariates (capital, skill supply, international outsourcing broad); country, sector and time dummies included in all specifications; all variables in natural logs and with respect to the EU27 average (ie. value of 0 on the horizontal axis corresponds to wage equal to the EU27 average). Regressions weighted by sector size
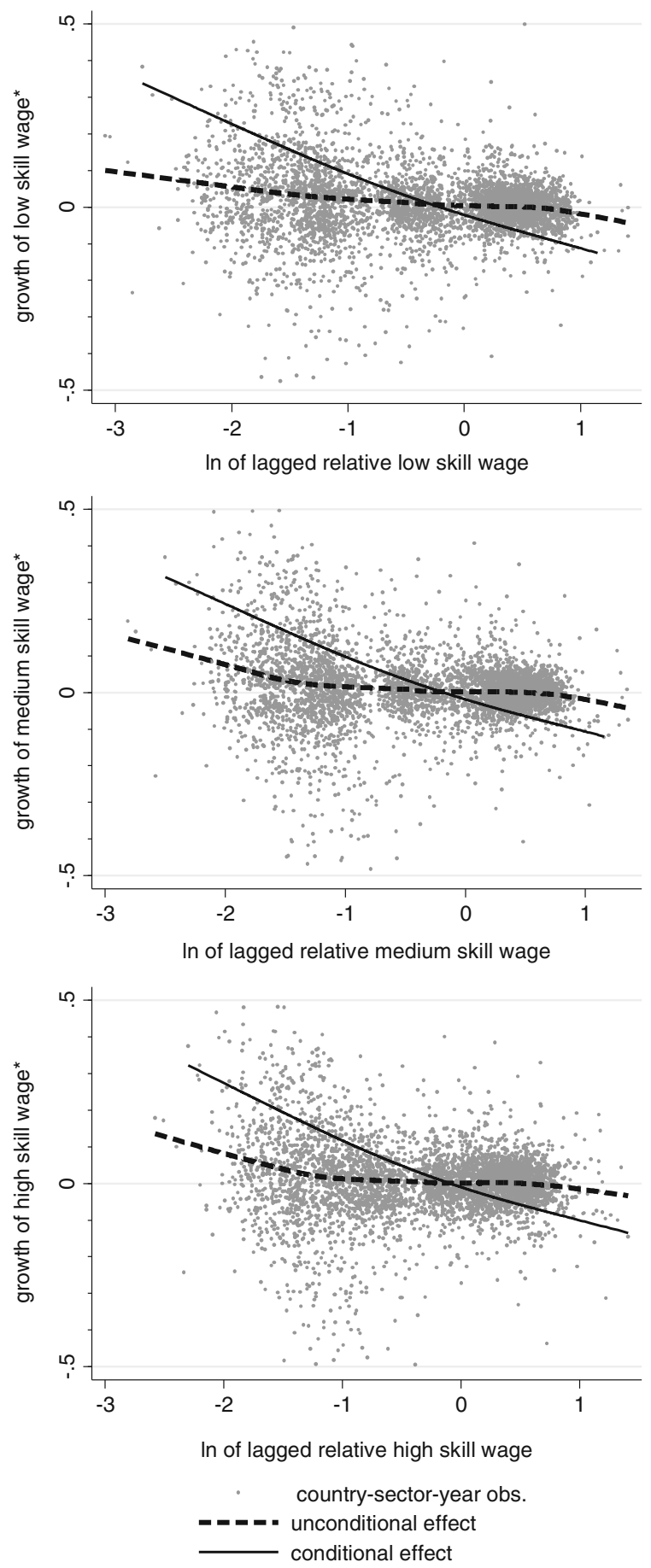
However, for all skill categories, this relationship is very weak (Fig. 6, dashed lines) and we can conclude that absolute convergence does not take place in our sample of EU countries. On the contrary, conditional convergence is much more pronounced (Fig. 6, solid lines).

\subsection{Estimation results}

The next tasks are: $(i)$ to check the statistical significance of the conditional wage convergence pattern for different types of workers, given the endogeneity in the model; (ii) to disentangle the wage growth effects and wage convergence effects, (iii) to evaluate the impact of alternative outsourcing types on wage growth and convergence, and assess the magnitude of the effect and its economic significance.

\subsubsection{Specification}

We are aware that some endogeneity problems may arise with our model. First, due to the inclusion of the lagged wage as an independent variable, either the pooled OLS or the fixed effects will be biased. ${ }^{26}$ Additionally, we do not expect wages and capital to be strictly exogenous (Blundell and Bond 1998). To ensure statistical accuracy, we use the system GMM (two-step) technique from the framework developed by Arellano and Bond (1991), where the endogenous variables are instrumented by their lags. Finally, a two-way relationship between wage growth and offshoring practices is plausible: if we assume that tasks are offshored mainly towards countries with lower wages, then wage growth can discourage the practice of task relocation. To ensure that we measure a causal effect of offshoring on wage growth (and not vice versa), instrumental variable techniques are employed. We build sector-level instruments for trade flows of intermediate goods on the basis of a gravity equation, following the procedure in Di Giovanni and Levchenko (2009), extending Frankel and Romer's (1999) methodology. ${ }^{27}$ The values of the AR(1) and AR(2) correlation and diagnostic tests - the Hansen J-test of joint validity of instruments and the DifferenceHansen tests of the validity of subsets of instruments (i.e. levels, differenced,

\footnotetext{
${ }^{26}$ For a formal exposition of the bias, see e.g. Arellano and Bond (1991) or Bond (2002).

${ }^{27}$ In particular we compute: IntOUT $T_{i j p t}=\alpha+\beta_{1} \ln V A_{i j t}+\beta_{2} \operatorname{lnVA} A_{p j t}+\beta_{3} \ln D_{i p}+\beta_{4}$ Contig $_{i p}+\beta_{5}$ RTA $_{i p t}+$ $\beta_{6}$ Comcur $_{i p}+\beta_{7}$ Comlang $_{i p}+\beta_{8}$ Colony $_{i p}+\varepsilon_{i j p t}$, where: IntOUT $i j p$, is bilateral trade of intermediate goods in sector $j$, from country $i$ (reporter/origin country) to country $p$ (partner/destination country), $\operatorname{lnVA}_{i j t}$ is the $\log$ of the reporter's value added, $\ln V A_{p j t}$ is the $\log$ of the partner's value added, $\ln D_{i p}$ is the $\log$ of the distance between $i$ and $p$, defined as the distance between the capital cities in the two countries, Contig $i p$ equals 1 if the two countries have a common land border, $R T A_{i p}$ equals 1 if both countries participate in a common regional trade agreement, Comcur $_{i p}$ indicates a dummy variable for whether the reporter and partner have a common currency, Comlang $_{i p}$ indicates a dummy variable for a common official language, and Colony $i p$ equals 1 if the two countries have ever been in a colonial relationship. The above gravity equation is estimated separately for each sector, using the Poisson Pseudo Maximum Likelihood method PPML (Santos Silva and Tenreyro 2006) - in order to take into account the information contained in the zero trade observations. Then, the predicted value of industry $j$ bilateral trade of intermediate goods from country $i$ to each of its partners is obtained (Int $\hat{O U} T_{i j p t}$ ). We further sum the predicted values of trade flows across all partner countries $p=1, \ldots, \mathrm{P}$ to obtain an overall trade flow for each sector analyzed for a given reporter country: Int $\hat{O U} T_{i j t}=\sum_{p=1}^{P}$ Int $O \hat{U} T_{i j p t}$. As an alternative (see Section 4.3), we sum the predicted trade flows across the EU27 and the NMS12 to obtain an instrument for trade with different partner groups. A similar sector-level instrument for trade has been used in Parteka and Wolszczak-Derlacz (2013).
} 
and standard IV) - for the most estimations show no evidence for misspecification of the estimated model, however if the diagnostics tests are not passed we interpret the result with caution. $^{28}$

After a stationarity check, ${ }^{29}$ we estimate models (7) and (8) for the wages of different skill categories. Table 1 presents the results for low-skilled wages, Table 2 for mediumskilled and Table 3 for high-skilled workers. We start our analysis with the absolute convergence (Column (1) of the respective tables), in which wage growth is regressed on its lagged levels according to Eq. 7. Then we report the estimates of the conditional beta convergence Eq. 8, when the process is controlled for the impact of the relative capital to labour ratio and the relative supply of each type of labour (Columns (2) of the tables). Finally, Columns (3) to (7) contain analogous results obtained when domestic outsourcing and offshoring intensity (i.e. narrow and broad) are taken into account. In particular, the results in Columns (6) and (7) refer to the autoregressive model (9) with an observationdependent autoregressive coefficient and an interaction term, which helps us analyse the effect of IntOUT on steady states (and can be interpreted as long-term influence on wage differential growth) as well on speed of convergence. Table 3A in the Appendix (Parteka, Wolszczak-Derlacz 2014) presents the summary statistics of all the variables used in the empirical model.

\subsubsection{Interpretation of the results}

The hypothesis of absolute convergence is rejected, which is consistent with earlier observations based on the empirical distributions of wage differentials and Fig. 6. Only in the case of the wages of low-skilled labour do we obtain a statistically significant and negative beta parameter (Column (1) of Table 1). However, its magnitude is very low and the speed of convergence equals $1 \%$, and consequently it may take more than 60 years for half of the

\footnotetext{
${ }^{28}$ According to Arrelano and Bond (1991), the GMM estimator requires first-order serial correlation (AR(1) test), but no second-order serial correlation in residuals (AR(2) test). Since the null hypotheses are that there is no first-/ second-order correlation, in the case of $\mathrm{AR}(1)$ the null hypothesis should be rejected but not in the case of $\mathrm{AR}(2)$. The results from Tables 1, 2 and 3 support the validity of the model specifications. Next, we report the results of the Hansen J test - a standard check for a two-step GMM estimator both considering instrument validity and structural specification (Roodman 2009). Except for the absolute convergence regression (Column 1) we cannot reject the null hypothesis of correct model specification and valid over-identifying restrictions. Additionally, we employ Difference-Hansen tests of the validity of the subsets of instruments. We cannot reject the null hypothesis of exogeneity of system GMM instruments, or validity of the IV instruments. In terms of the robustness of the estimation method, we additionally follow the suggestion by Bond (2002) to examine the dynamic GMM validity by checking (apart from using standard diagnostic tests) if the estimated coefficient on the lagged dependent variable lies between the ones obtained from OLS and FE estimations. This condition is confirmed (i.e. in low-skilled wages model with broad offshoring, the values of the coefficient are as follows: $\mathrm{OLS}=-0.062, \mathrm{GMM}=-0.090, \mathrm{FE}=-0.412$ ).

${ }^{29}$ The convergence hypothesis assumes that wage differences (we use log differentials of domestic wage relative to the EU-27 average) across locations must be stationary. Thus we previously check for unit roots in the panel. We perform the Fisher test for the panel unit root using an augmented Dickey-Fuller test, as it allows for the gaps in the panel (Table 4A in the Appendix of Parteka, Wolszczak-Derlacz 2014). Due to the limited time period, the number of lags was restricted to 1 . The null hypothesis of the unit root is rejected in all cases at standard levels of confidence.
} 
Table 1 Estimation results of wage convergence model (manufacturing sectors, EU27, 1995-2009) Low-skilled wages, dependent variable: wage growth $\Delta \ln \left(\mathrm{w}_{\mathrm{ijt}}\right)$

\begin{tabular}{|c|c|c|c|c|c|c|c|c|}
\hline & (1) & (2) & (3) & (4) & (5) & (6) & (7) & (8) \\
\hline $\ln w_{i j t-1}$ & $\begin{array}{l}-0.012 * * \\
{[0.003]}\end{array}$ & $\begin{array}{c}*_{-}-0.093 * * * \\
{[0.020]}\end{array}$ & $\begin{array}{l}{ }^{*}-0.101 * * * \\
{[0.025]}\end{array}$ & $\begin{array}{l}{ }^{*}-0.145^{* * * *} \\
{[0.026]}\end{array}$ & $\begin{array}{l}{ }^{*}-0.086^{* * * *} \\
{[0.021]}\end{array}$ & $\begin{array}{l}{ }^{-}-0.092 * * * \\
{[0.020]}\end{array}$ & $\begin{array}{l}-0.091 * * * \\
{[0.020]}\end{array}$ & $\begin{array}{l}{ }^{*}-0.090 * * * \\
{[0.020]}\end{array}$ \\
\hline $\ln k_{i j t}$ & & $\begin{array}{l}0.086^{* * * *} \\
{[0.023]}\end{array}$ & $\begin{array}{l}0.097 * * * \\
{[0.028]}\end{array}$ & $\begin{array}{l}0.143 * * * \\
{[0.026]}\end{array}$ & $\begin{array}{l}0.074 * * * \\
{[0.024]}\end{array}$ & $\begin{array}{l}0.078 * * * \\
{[0.019]}\end{array}$ & $\begin{array}{l}0.065 * * * \\
{[0.020]}\end{array}$ & $\begin{array}{l}0.073 * * * \\
{[0.019]}\end{array}$ \\
\hline $\ln l a b_{i j_{\mathrm{t}}}$ & & $\begin{array}{l}-0.004 \\
{[0.003]}\end{array}$ & $\begin{array}{l}-0.003 \\
{[0.004]}\end{array}$ & $\begin{array}{l}-0.001 \\
{[0.003]}\end{array}$ & $\begin{array}{l}-0.012 * * \\
{[0.006]}\end{array}$ & $\begin{array}{l}-0.021 * * * \\
{[0.006]}\end{array}$ & $\begin{array}{l}-0.012 * * * \\
{[0.004]}\end{array}$ & $\begin{array}{l}{ }^{*}-0.017 * * * \\
{[0.005]}\end{array}$ \\
\hline $\ln d o m \_o u t_{i j t}^{N}$ & & & $\begin{array}{l}-0.005 \\
{[0.008]}\end{array}$ & & & & & \\
\hline $\ln d o m \_o u t_{i j t}^{B}$ & & & & $\begin{array}{l}-0.100 * * * \\
{[0.025]}\end{array}$ & & & & \\
\hline $\operatorname{lnint} \_o u t_{i j t}^{N}$ & & & & & $\begin{array}{l}-0.041 * * \\
{[0.019]}\end{array}$ & & $\begin{array}{l}-0.050 * * * \\
{[0.019]}\end{array}$ & \\
\hline $\ln i n t \_o u t_{i j t}^{B}$ & & & & & & $\begin{array}{l}-0.089 * * * \\
{[0.027]}\end{array}$ & & $\begin{array}{l}-0.077 * * * \\
{[0.027]}\end{array}$ \\
\hline $\ln i n t_{-} o u t_{i j t}^{N} \mathrm{x} \ln w_{i j t_{-1}}$ & & & & & & & $\begin{array}{l}-0.013 \\
{[0.012]}\end{array}$ & \\
\hline $\ln i n t_{-} o u t_{i j t}^{B} \mathrm{x} \ln w_{i j t_{-1}}$ & & & & & & & & $\begin{array}{l}0.006 \\
{[0.018]}\end{array}$ \\
\hline Observations & 4835 & 4446 & 4424 & 4446 & 4446 & 4446 & 4446 & 4446 \\
\hline Groups & 349 & 349 & 348 & 349 & 349 & 349 & 349 & 349 \\
\hline $\begin{array}{l}\text { Instruments } \\
\text { Diagnostics }\end{array}$ & 104 & 195 & 285 & 285 & 286 & 286 & 287 & 287 \\
\hline $\mathrm{AR}(1)$ & 0.000 & 0.000 & 0.000 & 0.000 & 0.000 & 0.000 & 0.000 & 0.000 \\
\hline $\operatorname{AR}(2)$ & 0.222 & 0.381 & 0.361 & 0.380 & 0.365 & 0.277 & 0.345 & 0.284 \\
\hline $\begin{array}{l}\text { Hansen J } \\
\text { Diff Hansen (p val) }\end{array}$ & 0.000 & 0.000 & 0.082 & 0.080 & 0.115 & 0.126 & 0.125 & 0.117 \\
\hline $\begin{array}{l}\text { GMM } \\
\text { differenced-instruments }\end{array}$ & 0.000 & 0.000 & 0.019 & 0.014 & 0.041 & 0.027 & 0.042 & 0.023 \\
\hline $\begin{array}{l}\text { System GMM } \\
\text { instruments }\end{array}$ & 0.783 & 0.980 & 0.969 & 0.988 & 0.910 & 0.990 & 0.929 & 0.992 \\
\hline $\begin{array}{l}\text { GMM instruments } \\
\text { without IV }\end{array}$ & 0.000 & 0.000 & 0.064 & 0.058 & 0.105 & 0.069 & 0.129 & 0.069 \\
\hline IV instruments & 0.181 & 0.100 & 0.628 & 0.705 & 0.492 & 0.938 & 0.370 & 0.878 \\
\hline
\end{tabular}

Notes: All variables expressed in relation to the EU27 mean. All estimations are two-step system GMM, with the weights corresponding to the sector size (total hours worked by persons engaged). Constants not reported. Robust standard errors in parentheses. Statistically significant at $* * * 1, * * 5$, *10 percent level. Country/industry fixed effects and year dummies are included in all regressions. Variables: $\ln \left(w_{i j t-1}\right), \ln k_{\mathrm{ijt}}$ and lndom_out $t_{i j t}$ are treated as endogenous and instrumented by their lags. In specifications (5), (6), (7) and (8) the instruments for offshoring penetration are based on the gravity equation described in the main text. The figures reported for the Arellano-Bond test for $\mathrm{AR}(1)$ and $\mathrm{AR}(2)$ are the p-values. The Hansen J-test of over-identifying restrictions corresponds to the H0: The model specification is correct and all overidentifying restrictions (all over-identified instruments) are correct (exogenous). Difference-Hansen tests: $\mathrm{H}_{0}$ GMM differenced instruments are exogenous; $\mathrm{H}_{0}$ System GMM instruments are exogenous and they increase the Hansen-J test result; $\mathrm{H}_{0}$ GMM instruments without IV instruments are exogenous; $\mathrm{H}_{0}$ Standard IV instruments are exogenous and they increase the Hansen-J test result 
Table 2 Estimation results of wage convergence model (manufacturing sectors, EU27, 1995-2009) Medium-skilled wages, dependent variable: wage growth $\Delta \ln \left(\mathrm{w}_{i j t}\right)$

\begin{tabular}{|c|c|c|c|c|c|c|c|c|}
\hline & (1) & (2) & (3) & (4) & (5) & (6) & (7) & (8) \\
\hline \multirow[t]{2}{*}{$\ln w_{i j t-1}$} & -0.009 & $-0.055^{* * *}$ & $-0.068 * * *$ & $-0.125 * * *$ & $-0.080 * * *$ & $-0.106 * * *$ & $-0.102 * * *$ & $-0.110 * * *$ \\
\hline & {$[0.006]$} & [0.020] & {$[0.020]$} & [0.026] & {$[0.018]$} & [0.024] & [0.023] & {$[0.025]$} \\
\hline \multirow[t]{2}{*}{$\ln k_{i j t}$} & & $0.051^{* * *}$ & $0.064 * * *$ & $0.123 * * *$ & $0.069 * * *$ & $0.093 * * *$ & $0.074 * * *$ & $0.096 * * *$ \\
\hline & & [0.018] & {$[0.020]$} & [0.023] & [0.018] & {$[0.020]$} & {$[0.018]$} & [0.021] \\
\hline \multirow[t]{2}{*}{$\ln l a b_{i j_{\mathrm{t}}}$} & & $-0.005^{* * *}$ & $-0.006^{* * *}$ & -0.003 & $-0.010 * * *$ & $-0.016^{* * *}$ & $-0.011 * * *$ & $-0.014 * * *$ \\
\hline & & {$[0.002]$} & [0.002] & [0.002] & [0.003] & [0.004] & {$[0.003]$} & [0.004] \\
\hline \multirow[t]{2}{*}{$\ln d o m_{-} o u t_{i j t}^{N}$} & & & 0.002 & & & & & \\
\hline & & & {$[0.005]$} & & & & & \\
\hline \multirow[t]{2}{*}{$\ln d o m_{-} o u t_{i j t}^{B}$} & & & & $-0.116^{* * *}$ & & & & \\
\hline & & & & {$[0.026]$} & & & & \\
\hline \multirow[t]{2}{*}{$\ln i n t \_o u t_{i j t}^{N}$} & & & & & $-0.040 * * *$ & & $-0.055 * * *$ & \\
\hline & & & & & {$[0.010]$} & & {$[0.018]$} & \\
\hline \multirow[t]{2}{*}{$\ln i n t \_o u t_{i j t}^{B}$} & & & & & & $-0.071 * * *$ & & $-0.067 * * *$ \\
\hline & & & & & & {$[0.018]$} & & {$[0.021]$} \\
\hline $\ln i n t \_o u t_{i j t}^{N}$ & & & & & & & -0.019 & \\
\hline $\mathrm{x} \ln w_{i j t_{-1}}$ & & & & & & & {$[0.019]$} & \\
\hline $\ln i n t \_o u t_{i j t}^{B}$ & & & & & & & & 0.011 \\
\hline $\mathrm{x} \ln w_{i j t_{-1}}$ & & & & & & & & {$[0.020]$} \\
\hline Observations & 4835 & 4446 & 4424 & 4446 & 4446 & 4446 & 4446 & 4446 \\
\hline Groups & 349 & 349 & 348 & 349 & 349 & 349 & 349 & 349 \\
\hline Instruments & 104 & 195 & 285 & 285 & 286 & 286 & 287 & 287 \\
\hline \multicolumn{9}{|l|}{ Diagnostics } \\
\hline $\mathrm{AR}(1)$ & 0.000 & 0.000 & 0.000 & 0.000 & 0.000 & 0.000 & 0.000 & 0.000 \\
\hline $\operatorname{AR}(2)$ & 0.072 & 0.09 & 0.121 & 0.09 & 0.097 & 0.097 & 0.093 & 0.098 \\
\hline Hansen J & 0.000 & 0.001 & 0.103 & 0.043 & 0.137 & 0.122 & 0.147 & 0.116 \\
\hline \multicolumn{9}{|c|}{ Diff Hansen (p val) } \\
\hline $\begin{array}{l}\text { GMM differenced- } \\
\text { instruments }\end{array}$ & 0.000 & 0.000 & 0.036 & 0.019 & 0.029 & 0.040 & 0.025 & 0.037 \\
\hline $\begin{array}{l}\text { System GMM } \\
\text { instruments }\end{array}$ & 0.793 & 0.760 & 0.908 & 0.733 & 0.991 & 0.937 & 0.998 & 0.938 \\
\hline $\begin{array}{l}\text { GMM instruments } \\
\text { without IV }\end{array}$ & 0.000 & 0.002 & 0.092 & 0.053 & 0.090 & 0.106 & 0.073 & 0.093 \\
\hline IV instruments & 0.056 & 0.023 & 0.509 & 0.222 & 0.834 & 0.540 & 0.975 & 0.616 \\
\hline
\end{tabular}

Notes: as under Table 1 
Table 3 Estimation results of wage convergence model (manufacturing sectors, EU27, 1995-2009) High-skilled wages, dependent variable: wage growth $\Delta \ln \left(w_{i j t}\right)$

\begin{tabular}{|c|c|c|c|c|c|c|c|c|}
\hline & (1) & (2) & (3) & (4) & (5) & (6) & (7) & (8) \\
\hline $\ln w_{i j t-1}$ & $\begin{array}{l}-0.006 \\
{[0.006]}\end{array}$ & $\begin{array}{l}-0.099 * * * \\
{[0.027]}\end{array}$ & $\begin{array}{l}-0.105 * * * \\
{[0.025]}\end{array}$ & $\begin{array}{l}-0.184 * * * \\
{[0.030]}\end{array}$ & $\begin{array}{l}-0.084 * * * \\
{[0.024]}\end{array}$ & $\begin{array}{l}-0.098 * * * \\
{[0.027]}\end{array}$ & $\begin{array}{l}-0.086^{* * * *} \\
{[0.028]}\end{array}$ & $\begin{array}{l}-0.086 * * * \\
{[0.032]}\end{array}$ \\
\hline $\ln \left(k_{\mathrm{ijt}}\right)$ & & $\begin{array}{l}0.077 * * * \\
{[0.020]}\end{array}$ & $\begin{array}{l}0.083 * * * \\
{[0.017]}\end{array}$ & $\begin{array}{l}0.153 * * * \\
{[0.025]}\end{array}$ & $\begin{array}{l}0.063 * * * \\
{[0.018]}\end{array}$ & $\begin{array}{l}0.074 * * * \\
{[0.022]}\end{array}$ & $\begin{array}{l}0.064 * * * \\
{[0.019]}\end{array}$ & $\begin{array}{l}0.070 * * * \\
{[0.023]}\end{array}$ \\
\hline $\ln l a b_{i j_{\mathrm{t}}}$ & & $\begin{array}{l}0.002 \\
{[0.003]}\end{array}$ & $\begin{array}{l}0.002 \\
{[0.004]}\end{array}$ & $\begin{array}{l}0.005 \\
{[0.003]}\end{array}$ & $\begin{array}{l}0.001 \\
{[0.003]}\end{array}$ & $\begin{array}{l}0.001 \\
{[0.004]}\end{array}$ & $\begin{array}{l}0.003 \\
{[0.003]}\end{array}$ & $\begin{array}{l}0.003 \\
{[0.004]}\end{array}$ \\
\hline $\ln d o m \_o u t_{i j t}^{N}$ & & & $\begin{array}{l}-0.002 \\
{[0.007]}\end{array}$ & & & & & \\
\hline $\ln d o m_{-} o u t_{i j t}^{B}$ & & & & $\begin{array}{l}-0.145^{* * *} \\
{[0.023]}\end{array}$ & & & & \\
\hline $\ln i n t \_o u t_{i j t}^{N}$ & & & & & $\begin{array}{l}-0.005 \\
{[0.012]}\end{array}$ & & $\begin{array}{l}-0.001 \\
{[0.015]}\end{array}$ & \\
\hline $\ln i n t_{-} o u t_{i j t}^{B}$ & & & & & & $\begin{array}{l}-0.012 \\
{[0.020]}\end{array}$ & & $\begin{array}{l}0.001 \\
{[0.021]}\end{array}$ \\
\hline $\begin{array}{l}\ln i n t_{-} o u t_{i j t}^{N} \\
\mathrm{x} \ln w_{i j t_{-1}}\end{array}$ & & & & & & & $\begin{array}{l}0.008 \\
{[0.016]}\end{array}$ & \\
\hline $\begin{array}{l}\ln I n t_{-} \text {out } t_{i j t}^{B} \\
\mathrm{x} \ln w_{i j t_{-1}}\end{array}$ & & & & & & & & $\begin{array}{l}0.026 \\
{[0.020]}\end{array}$ \\
\hline Observations & 4835 & 4446 & 4424 & 4446 & 4446 & 4446 & 4446 & 4446 \\
\hline Groups & 349 & 349 & 348 & 349 & 349 & 349 & 349 & 349 \\
\hline Instruments & 104 & 195 & 285 & 285 & 286 & 286 & 287 & 287 \\
\hline Diagnostics & & & & & & & & \\
\hline $\operatorname{AR}(1)$ & 0.000 & 0.000 & 0.000 & 0.000 & 0.000 & 0.000 & 0.000 & 0.000 \\
\hline $\operatorname{AR}(2)$ & 0.112 & 0.121 & 0.155 & 0.111 & 0.12 & 0.12 & 0.122 & 0.122 \\
\hline Hansen J & 0.000 & 0.004 & 0.131 & 0.125 & 0.154 & 0.115 & 0.130 & 0.169 \\
\hline Diff Hansen ( $\mathrm{p}$ val) & & & & & & & & \\
\hline $\begin{array}{l}\text { GMM differenced- } \\
\text { instruments }\end{array}$ & 0.000 & 0.001 & 0.024 & 0.030 & 0.110 & 0.032 & 0.113 & 0.031 \\
\hline $\begin{array}{l}\text { System GMM } \\
\text { instruments }\end{array}$ & 0.026 & 0.774 & 0.996 & 0.981 & 0.619 & 0.958 & 0.477 & 0.998 \\
\hline $\begin{array}{l}\text { GMM instruments } \\
\text { without IV }\end{array}$ & 0.000 & 0.005 & 0.144 & 0.083 & 0.175 & 0.101 & 0.172 & 0.097 \\
\hline IV instruments & 0.008 & 0.174 & 0.307 & 0.824 & 0.277 & 0.528 & 0.177 & 0.934 \\
\hline
\end{tabular}

Notes: as under Table 1 
gap in low-skill wages to disappear (a half-life of 64 years). ${ }^{30}$ Additionally, these results should be interpreted with caution as they do not pass the Hansen J test.

Consequently, we proceed with the estimation of conditional wage convergence. As reported in Columns (2) to (7) for all skills categories, a negative and statistically significant coefficient on the lagged wage is obtained in accordance with the conditional convergence hypothesis and in line with Fig. 6 . The coefficients associated with the additional covariates are mostly significant and as predicted by economic theory (positive in the case of the capital-labour ratio, $k$, and negative in the case of skill-specific supply, $l a b$ ).

Is domestic outsourcing playing a role? A statistically significant and negative effect on wage growth (for all skill categories) is obtained only when DomOUT is measured in the broad sense (Column (4)). Thus, the process of task relocation to other sectors within the same country can negatively affect workers when activities are domestically outsourced.

Now we turn to our main variable of interest: international outsourcing (IntOUT), ${ }^{31}$ measured in the narrow sense (results in Column (5)) and in the broad sense (results in Column (5)), and always instrumented. There are some differences in the impact of international outsourcing on the wages of workers according to skill level. A negative and statistically significant parameter associated with international outsourcing (both narrow and broad measures) is only obtained for the wage growth of low- and medium-skilled workers. This would be consistent with the concept that offshoring practices hurt workers with lower skill levels (Wood 1995; Feenstra and Hanson 1999; Geishecker and Görg 2008; Hummels et al. 2011). However, we will show that this negative impact is economically relatively negligible.

The results obtained with the interaction term (note its statistically insignificant coefficient in Columns 7 and 8) indicate that international outsourcing (both narrow and broad) appears to negatively affect the steady state of each industry's wage differentials (as in the equation without the interaction term) but does not influence the speed of adjustment. This holds for the wages of low- and medium-skilled workers (Tables 1 and 2) and means that even if offshoring affects the wage growth of less skilled workers, it does not affect the wage convergence process. Moreover, international outsourcing affects neither wage growth nor wage convergence in the case of high-skilled labour (Columns 7 and 8 of Table 3).

\subsubsection{Economic significance}

So far, we have concentrated on the statistical interpretation of the results obtained, indicating some negative effects of international outsourcing on the wage growth of domestic workers with education below university level. However, it is crucial to check the magni-

\footnotetext{
${ }^{30}$ The relatively small coefficients on the lagged wage variables indicate that the series are highly persistent so that their own lagged levels are weak instruments for subsequent changes. This is confirmed by the Hansen J diagnostic test. As noted by Roodman (2009), the Hansen J test of over-identifying restriction in the case of non-rejection of the null hypothesis may not only indicate weak instruments but also some misspecification e.g. omitting important explanatory variables.

${ }^{31}$ We do not include the variables of domestic outsourcing and offshoring in one regression due to possible collinearity problems. The coefficient on the correlation between domestic outsourcing and offshoring equals 0.76 and 0.81 for the narrow and broad measures respectively. Similarly, we cannot account for the overall degree of openness of a given sector (imp/VA or $\exp / V A$ ) as these measures are highly correlated with the outsourcing ones (the correlation coefficient is in the range from 0.81 to 0.92 for import/export penetration and narrow/broad offshoring penetration respectively).
} 
Table 4 Assessment of economic significance - real wages (earnings) and the assessed marginal impact of offshoring on wages (and aggregate earnings) of low- and medium-skilled workers (1995-2009)

\begin{tabular}{|c|c|c|}
\hline & Low skilled & Medium skilled \\
\hline Hourly wage level $1995(\mathrm{EUR} / \mathrm{h})^{*}$ - real data & 20.6 & 25.1 \\
\hline $\begin{array}{l}\text { Estimated cumulative marginal effect of narrow offshoring } \\
\text { on hourly wages in } 14 \text { years }\end{array}$ & $\downarrow$ by $0.22 \mathrm{EUR} / \mathrm{h}$ & $\downarrow$ by $0.29 \mathrm{EUR} / \mathrm{h}$ \\
\hline $\begin{array}{l}\text { Estimated cumulative marginal effect of broad offshoring } \\
\text { on hourly wages in } 14 \text { years }\end{array}$ & $\downarrow$ by 0.18 EUR/h & $\downarrow$ by $0.19 \mathrm{EUR} / \mathrm{h}$ \\
\hline Total average earnings $1995-2009\left(E^{*}{ }^{*}\right)$ - real data & 618527.3 EUR & 775005.4 EUR \\
\hline $\begin{array}{l}\text { Estimated cumulative marginal effect of narrow offshoring } \\
\text { on aggregate earnings in } 14 \text { years }\end{array}$ & $\downarrow$ by 403 EUR & $\downarrow$ by 491 EUR \\
\hline $\begin{array}{l}\text { Estimated cumulative marginal effect of broad offshoring } \\
\text { on aggregate earnings in } 14 \text { years }\end{array}$ & $\downarrow$ by 346 EUR & $\downarrow$ by 367 EUR \\
\hline
\end{tabular}

Notes: *real wages expressed in 2009 constant terms. $\downarrow=$ downward push (negative marginal effect on wages). Calculation based on estimation results of model 9 reported in Columns 7 and 8 of Tables 1 and 2

tude of the coefficients estimated to obtain an idea of their economic significance. ${ }^{32} \mathrm{We}$ will focus on offshoring and the politically relevant and widely debatable link between task relocation abroad and the domestic wages of medium- and low-skilled workers. Our results should be read bearing in mind that we are only able to account for the impact of effective offshoring as registered in the data (and not accounting for indirect effects of it, i.e. acting as a threat in wage bargaining).

Our interpretation is based on the statistically significant results from Tables 1 and 2. The coefficient estimates for narrow offshoring indicate that (in line with the model transformation shown in footnote 22) a $10 \%$ increase is associated with a relative wage drop of around $0.5 \%$ for low- and medium-skilled labour (point estimates from Columns 7 of Tables 1 and 2). In the case of broad offshoring, the drop is of $0.77 \%$ and $0.67 \%$ for low- and mediumskilled workers respectively (Columns 8 of Tables 1 and 2). The question arises of whether these changes in wage levels resulting from offshoring are economically significant.

For an illustration, we calculate the cumulative marginal effects. These are based on the change in offshoring intensity observed in the data, combined with a point estimate of the offshoring coefficients (from the wage growth equation) and the average wage for the low- and medium-skilled category in the initial year of our analysis (1995). The results are presented concisely in Table 4 and Fig. 7.

Overall, between 1995 and 2009 narrowly-defined relative offshoring intensity increased by $21 \%$ (11\% in the case of broad offshoring). We can easily calculate that this rise in offshoring provoked a cumulative (between 1995 and 2009) downward pressure on lowskilled wages equivalent to only a $1.06 \%(=0.05 * 21 \%)$ wage drop $(0.87 \%$ in the case of broad offshoring). To enable a better understanding of the effects of offshoring in 'money' terms, we can express these figures in relation to the average wage levels from 1995 (see Table 4). In the fourteen years of our analysis, offshoring pushed down hourly low-skilled

\footnotetext{
${ }^{32}$ We follow Geishecker and Görg (2008), who provide an exercise of this sort analyzing the case of German workers. They estimate that increased international outsourcing between 1991 and 2000 accounts for an hourly wage reduction (for the low-skilled) of $€ 0.57$ and $€ 0.86$ for narrow and broad outsourcing respectively.
} 

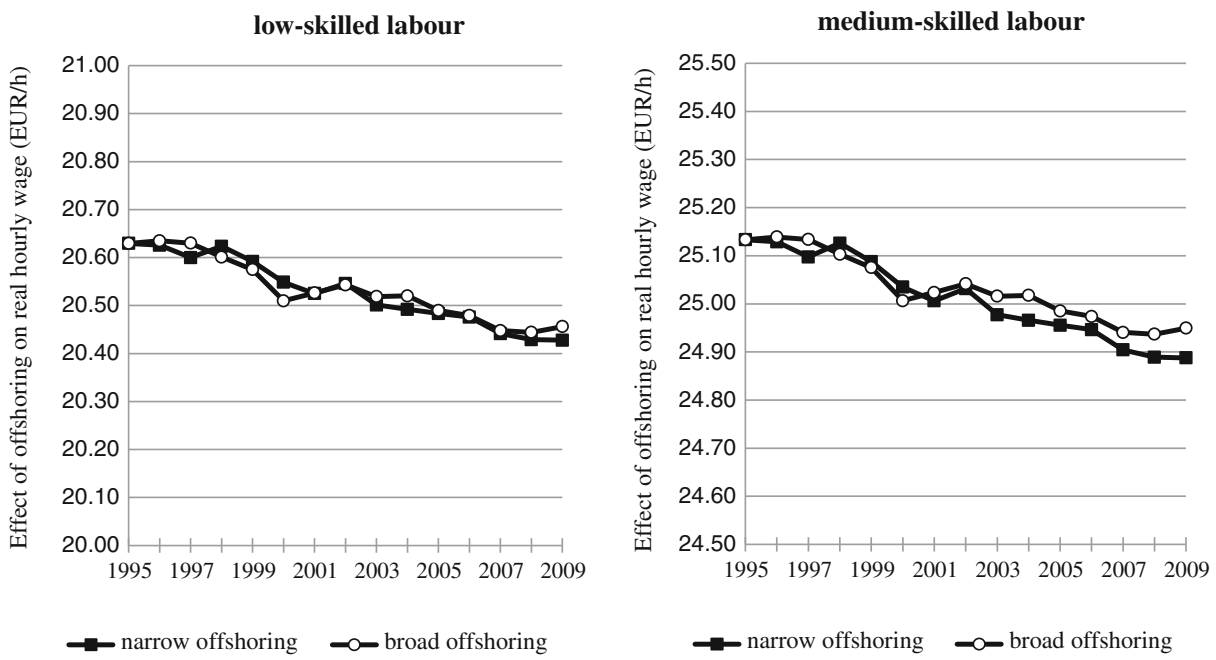

Fig. 7 Cumulated marginal effects of offshoring on real hourly wages (EUR/h) for domestic low-skilled labour (left-hand panel) and domestic medium-skilled labour (right-hand panel). Notes: cumulated marginal effects based on point estimates from Tables 1 and 2; wages are weighted averages across 13 manufacturing sectors and EU27 countries; weights correspond to sector size (employment)

wages by 0.22 EUR (0.18 EUR) - see also Fig. 7, left-hand panel. Multiplying this effect by the approx. number of hours worked by a single employee (e.g. 2000 hours per year ${ }^{33}$ ), this would imply a downward push on total (summed over the years 1995-2009) earnings of approximately 403 EUR (346 EUR) per worker. Given the magnitude of the total earnings of low-skilled workers registered in these years $(618,527$ EUR), we argue that this is hardly any effect - in the absence of offshoring the low skilled would have earned only $0.065 \%$ more.

The same exercise can be performed for medium-skilled workers (Fig. 7, right-hand panel, Table 4). The point estimates (from Table 2) indicate that in the period 1995-2009 a $10 \%$ rise in narrow (broad) offshoring is associated with a $0.55 \%(0.67 \%)$ downward push on their wages. Given the real change in narrow (broad) offshoring registered in the years analysed, this accounts for a reduction in medium-skilled wages over 14 years of only $1.16 \%(0.76 \%)$, which is equivalent to 0.29 EUR (0.19 EUR). Again, this total 'loss' due to offshoring accounts for only a very small fraction, namely $0.063 \%(0.047 \%)$, of the aggregate earnings of the medium skilled in the years 1995-2009.

The estimated cumulative marginal effect of narrow offshoring (reflecting cross-border production fragmentation taking place within the industry) on wages, exhibited in the 14 years analysed, is (a little) stronger than the effects of cross-industry production sharing (broad offshoring). Still, overall we can conclude that the downward push on wages of less skilled European workers due to offshoring (independently of the measure of it) is indeed economically (and socially) somewhat small.

\footnotetext{
${ }^{33}$ This value differs across countries and sectors. For simplicity, we assume approx. 38 hours worked per week.
} 


\subsection{Robustness checks}

The robustness of the estimation results is assessed in several ways. ${ }^{34}$ First, we augment the regression with additional covariates on labour market conditions (we consider the unemployment rate, migration flows and labour market institutions affecting wage-setting mechanism characteristics). Next, in order to check whether the effects of offshoring are alike for the three different skill groups in Western and Eastern European countries, we consider two alternatives to our basic global measure of offshoring: we calculate measures encompassing imports of intermediates from manufacturing sectors located in the EU27 only, and alternatively in the NMS12 countries only. We also augment the baseline estimation by introducing an EU15 dummy variable and an interaction term between it and offshoring. Then we take into consideration the variability of wage rigidity among the countries analysed-we divide countries according to the dominant level at which wage bargaining is coordinated. The subsequent robustness check concerns the way we calculate wages: instead of utilizing nominal exchange rates, we convert wages using PPPs. We conclude our sensitivity analysis by exploring cross-industry heterogeneity.

It should be stated that the magnitude of the parameters for offshoring obtained from all these alternative specifications does not differ dramatically from that described in the previous section. The conclusion that a reduction in relative wages due to international outsourcing is economically insignificant is sustained.

\section{Conclusions}

This paper has contributed to the literature on real convergence and the implications of economic integration for labour markets by investigating the effects of offshoring on wage growth and wage equalization in Europe. To the best of our knowledge, this is the first paper to provide empirical evidence on this topic in such a wide context (a sample of 13 manufacturing sectors in the EU27 countries, including both old and new member states, in the period 1995-2009). Importantly, with the use of recent data (coming from the WIOD project) and in line with recent literature that introduces worker heterogeneity into models of international trade, we have been able to discriminate between heterogeneous wage effects for different categories of workers (low, medium and high skill).

The main focus has been on the labour market outcomes of vertical integration, so we have augmented a model of conditional wage convergence through the inclusion of precise sector-specific broad and narrow outsourcing/offshoring indices based on input-output data (also from the WIOD). Two-way relations between trade variables (outsourcing) and wages have additionally been addressed through the use of a gravity-grounded sector-level instrument.

Our results confirm that despite a considerable rise in trade integration, which is also visible in cross-border flows of intermediates, there is no evidence supporting absolute skill-specific wage convergence in the EU27. Both descriptive evidence and the results obtained from the regression models estimated show that wage differentials in the EU27

\footnotetext{
${ }^{34}$ For the complete description and all the results referring to the robustness checks, we redirect the reader to the full version of the paper: Parteka and Wolszczak-Derlacz (2014).
} 
prove to be highly persistent. These results are in line with previous studies documenting strong cross-country wage differentials (Magda et al. 2011) combined with a lack of a (or a very slow) wage equalization process in Europe (e.g. Mora et al. 2005) and rejection of an unconditional wage convergence hypothesis (Egger and Pffaffermayr 2004).

Our regression results indicate that offshoring (like broad domestic outsourcing) negatively affects wage growth (but does not affect cross-country wage equalization). This negative impact of international outsourcing on wage growth is not homogeneous across the various categories of labour: only medium- and low-skilled workers in domestic sectors are involved. However, we have also made an additional effort to complement the estimates of the statistical significance of the impact of offshoring on wages with estimates of its economic significance. We argue that the magnitude of this effect (calculated in terms of real wage change and compared to overall earnings) is small and low/medium-skilled workers cannot therefore be perceived as losers from the integration process, at least in terms of wages.

Hence, we do not find a significant impact of offshoring practices in Europe on the process of wage equalization in EU sectors once the whole enlarged EU (EU15+CEE) is taken into account. How can we interpret this result in relation to the previous findings? Egger and Egger (2002) document that trade in intermediate goods drove up wages in manufacturing sectors in Central and Eastern Europe (CEE) in the 1990s. Egger and Pffaffermayr (2004) argue that this trade facilitated international factor price equalization in a sample composed of EU15 and 5 CEE countries (1993-2000), in line with Deardorff's (2001) model, while Egger (2006) finds a similar effect within CEE countries (1993-1999). First of all, it is difficult to relate our findings to these results due to sample composition (our is wider) and crucial methodological differences in the outsourcing measurement (we employ precise outsourcing measures based on input-output tables instead of using crude information on trade in intermediate goods). Moreover, nowadays the story can be very different from that typical for the first wave of intense outsourcing to CEE in 1990s. Low- and medium-skilled wages in CEE can now be pushed downwards due to an increasing importance of cheaper outsourcing destinations outside the EU so we do not see them catching up with Western European standards.

Of course, we are aware of the fact that the adjustment resulting from outsourcing may pass through quantities (employment levels) and not salaries, especially if wages are rigid. ${ }^{35}$ Examination of the employment channel goes beyond the scope of this paper but it could be a valuable complementary extension of our work, especially given the data availability stemming from the WIOD project. It would also be interesting to investigate in more detail the aspects related to wage rigidity/elasticity (e.g. the average agreement length of wage negotiations, minimum wages) and their role in affecting the offshoring-wage nexus. An additional focus could consider the assessment of 'club convergence' effects of offshoring in Europe.

Open Access This article is distributed under the terms of the Creative Commons Attribution License which permits any use, distribution, and reproduction in any medium, provided the original author(s) and the source are credited.

\footnotetext{
${ }^{35}$ Some studies (eg. Hijzen and Swaim 2007; Amiti and Wei 2009, Michel and Ryck 2012) show that offshoring does not result in net employment losses at the level of the industry or even the firm. The effects can, though, consider changes in occupational structure and job polarization due to the so-called 'routinization' (as shown in Acemoglu and Autor, 2011 examining the U.S./OECD case or in Goos et al. 2009 focusing on Europe).
} 


\section{References}

Acemoglu, D., Autor, D.H.: Skills, Tasks and technologies: implications for employment and earnings. In: Ashenfelter, O., Card, D.E. (eds.): Handbook of Labor Economics, vol. 4. Elsevier, Amsterdam (2011)

Acemoglu, D., Gancia, G., Zilibotti, F.: Offshoring and directed technical change. NBER Working Paper No. 18595. National Bureau of Economic Research (2012)

Amiti, M., Wei, S.J.: Does service offshoring lead to job losses? Evidence from the United States. In: International Trade in Services and Intangibles in the Era of Globalization, pp. 227-243. University of Chicago Press (2009)

Andersen, T.M., Haldrup, N., Sørensen, J.R.: Labour market implications of EU product market integration. Econ. Policy 15(30), 105-134 (2000)

Arellano, M., Bond, S.R.: Some tests of specification for panel data: monte carlo evidence and an application to employment equations. Rev. Econ. Studies 58(2), 277-297 (1991)

Baldone, S., Sdogati, F., Tajoli, L.: Patterns and determinants of international fragmentation of production: evidence from outward processing trade between the EU and Central Eastern European countries. Weltwirtschaftliches Arch. 137(1), 80-104 (2001)

Baldwin, R., Robert-Nicoud, F.: Trade-in-goods and trade-in-tasks: An integrating framework. J. Int. Econ. 92(1), 51-62 (2014)

Barro, R.J.: Economic growth in a cross section of countries. Q. J. Econ. 106(2), 407-443 (1991)

Barro, R.J.: Convergence and modernization revisited. NBER Working Papers No. 18295. National Bureau of Economic Research (2012)

Barro, R.J., Sala-i-Martin, X.: Convergence. J. Political Econ. 100(2), 223-251 (1992)

Barro, R.J., Sala-i-Martin, X.: Economic Growth. The MIT Press, Cambridge (MA) (2004)

Barro, R.J., Sala-i-Martin, X., Blanchard, O.J., Hall, R.E.: Convergence across states and regions. Brook. Pap. Econ. Act. 1, 107-182 (1991)

Bartkowska, M., Riedl, A.: Regional convergence clubs in Europe: Identification and conditioning factors. Econ. Modell. 29(1), 22-31 (2012)

Baumol, W.J.: Productivity growth, convergence, and welfare: what the long-run data show. Am. Econ. Rev. 76(5), 1072-1085 (1986)

Blundell, R., Bond, S.: Initial conditions and moment restrictions in dynamic panel data models. J. Econ. 87, 115-143 (1998)

Bond, S.: Dynamic panel data models: A guide to micro data methods and practice, Cemmap Working Paper CWP09/02. The Institute for Fiscal Studies, Department of Economics, UCL (2002)

De Long, J.B.: Productivity growth, convergence, and welfare: comment. Am. Econ. Rev. 78(5), 1138-1154 (1988)

Deardorff, A.V.: Fragmentation in simple trade models. N. Am. J. Econ. Finan. 12(2), 121-137 (2001)

Di Giovanni, J., Levchenko, A.A.: Trade openness and volatility. Rev. Econ. Stat. 91(3), 558-585 (2009)

Dietzenbacher, E., Los, B., Stehrer, R., Timmer, M., De Vries, G.: The construction of world input-output tables in the WIOD project. Econ. Syst. Res. 25(1), 71-98 (2013)

Egger, P.: Intermediate goods trade and international wage convergence in Central Europe. Empirica 33(4), 181-192 (2006)

Egger, H., Egger, P.: How international outsourcing drives up Eastern European wages. Weltwirtschaftliches Arch. 138(1), 83-96 (2002)

Egger, P., Pfaffermayr, M.: Two dimensions of convergence: national and international wage adjustment effects of cross-border outsourcing in europe. Rev. Int. Econ. 12(5), 833-843 (2004)

Egger, P., Stehrer, R.: International outsourcing and the skill-specific wage bill in eastern Europe. World Econ. 26(1), 61-72 (2003)

Esposito, P., Stehrer, R.: The sector bias of skill-biased technical change and the rising skill premium in transition economies. Empirica 36(3), 351-364 (2009)

Feenstra, R.C.: Offshoring in the Global Economy: Microeconomic Structure and Marcoeconomic Implications. The MIT Press, Cambridge, MA (2010)

Feenstra, R.C., Hanson, G.H.: Globalization, Outsourcing, and Wage Inequality. Am. Econ. Rev. 86(2), 24045 (1996)

Feenstra, R.C., Hanson G.H.: The impact of outsourcing and high-technology capital on wages: Estimates for the United States, 1979-1990. Q. J. Econ. 114, 907-941 (1999)

Feenstra, R., Hanson, G.H.: Global production sharing and rising inequality: A survey of trade and wages. NBER Working Paper No. 8372. National Bureau of Economic Research (2001) 
Feenstra, R.C., Jensen, J.B.: Evaluating estimates of materials offshoring from US manufacturing. Econ. Lett. 117(1), 170-173 (2012)

Frankel, J.A., Romer, D.: Does trade cause growth? Am. Econ. Rev. 89(3), 379-399 (1999)

Geishecker, I., Görg, H.: Winners and losers: A micro-level analysis of international outsourcing and wages. Can. J. Econ./Revue Canadienne d'Economique 41(1), 243-270 (2008)

Goos, M., Manning, A., Salomons, A.: Job polarization in Europe. Am. Econ. Rev. 99(2), 58-63 (2009)

Grossman, G.M., Rossi-Hansberg, E.: Trading tasks: A simple theory of offshoring. Am. Econ. Rev. 98(5), 1978 (2008)

Grossman, G.M., Rossi-Hansberg, E.: Task trade between similar countries. Econometrica 80(2), 593-629 (2012)

Grossman, G.E.: Heterogenous workers and international trade. Rev. World Econ. 149(2), 211-245 (2013)

Head, K., Mayer, T.: Gravity equations: toolkit, cookbook, workhorse. In: Gopinath, Helpman, and Rogoff (eds.) Handbook of International Economics, vol. 4, pp. 131-195. Elsevier (2015)

Hijzen, A., Swaim, P.: Does offshoring reduce industry employment? Nat. Inst. Econ. Rev. 201(1), 86-96 (2007)

Hummels, D., Jørgensen, R., Munch, J.R., Xiang, C.: The wage effects of offshoring: Evidence from Danish matched worker-firm data. NBER Working Papers No. 17496. National Bureau of Economic Research (2011)

Jones, R.W., Kierzkowski, H.: The role of services in production and international trade: A theoretical framework. In: Jones, R., Krueger, A. (eds.) Basil Blackwell, Oxford (1990)

Jones, R.W., Kierzkowski, H.: Globalization and the consequences of international fragmentation. In: Dornbusch, R., Calvo, G., Obsfeld, M. (eds.) MIT Press, Cambridge, MA (1998)

Kohler, W.: Aspects of international fragmentation. Rev. Int. Econ. 12(5), 793-816 (2004)

Magda, I., Rycx, F., Tojerow, I., Valsamis, D.: Wage differentials across sectors in Europe. Econ. Trans. 19(4), 749-769 (2011)

Marin, D.: A new international division of labor in Europe: Outsourcing and offshoring to Eastern Europe. J. Eur. Econ. Assoc. 4(2-3), 612-622 (2006)

Markusen, J.: Modeling the offshoring of white-collar services: from comparative advantage to the new theories of trade and FDI. NBER Working Papers No. 11827. National Bureau of Economic Research (2005)

Michel, B., Rycx, F.: Does offshoring of materials and business services affect employment? Evidence from a small open economy. Appl. Econ. 44(2), 229-251 (2012)

Michel, B., Rycx, F.: Productivity gains and spillovers from offshoring. Rev. Int. Econ. 22(1), 73-85 (2014)

Mora, T., Lopez-Tamayo, J., Suriñach, J.: Are wages and productivity converging simultaneously in Euroarea countries? Appl. Econ. 37(17), 2001-2008 (2005)

Onaran, O., Stockhammer, E.: The effect of FDI and foreign trade on wages in the Central and Eastern European Countries in the post-transition era: A sectoral analysis for the manufacturing industry. Struct. Chang. Econ. Dyn. 19(1), 66-80 (2008)

Parteka, A., Wolszczak-Derlacz, J.: The impact of trade integration with the EU on productivity in a posttransition economy. The case of Polish manufacturing sectors. Emerg. Mark. Finance Trade 49(2), 84104 (2013)

Parteka A., Wolszczak-Derlacz, J.: Integrated sectors - diversified earnings: the (missing) impact of offshoring on wages and wage convergence in the EU27 [revised, full version]. GUT FME Working Paper Series A, No.5/2014(24). Gdansk (Poland): Gdansk University of Technology, Faculty of Management and Economics ftp://ftp.zie.pg.gda.pl/RePEc/gdk/wpaper/WP_GUTFME_A_24_ PartekaWolszczakDerlacz.pdf (2014)

Polgár, É., Wörz, J.: No risk and some fun? Trade and wages in the enlarged European Union. Empirica 37(2), 127-163 (2010)

Ramskogler, P.: The state of wage convergence in the European Monetary Union. Department of economics working paper series No. 130. WU Vienna University of Economics and Business, Vienna (2010)

Ramskogler, P.: Is there a European wage leader? Wage spillovers in the European Monetary Union. Camb. J. Econ. 36(4), 941-962 (2012)

Rodrik, D.: The future of economic convergence. NBER Working Paper No. 17400. National Bureau of Economic Research (2011)

Roodman, D.: A Note on the Theme of Too Many Instruments. Oxf. Bull. Econ. Stat. 71, 135-158 (2009)

Santos Silva, M.C., Tenreyro, S.: The log of gravity. Rev. Econ. Stat. 88(4), 641-658 (2006)

Schwörer, T.: Offshoring, domestic outsourcing and productivity: evidence for a number of European countries. Rev. World Econ. 149(1), 131-149 (2013) 
Timmer M., Erumban A.A., Gouma R., Los B., Temurshoev U., de Vries G.J., Arto I., Andreoni V., Genty A., Neuwahl F., Rueda-Cantuche J.M., Villanueva A., Francois J., Pindyuk O., Pöschl J., Stehrer R., Estreicher G.: The World Input-Output Database (WIOD): Contents, Sources and Methods. April 2012, Version 0.9. Downloadable at http://www.wiod.org/publications/source_docs/WIOD_sources.pdf (2012)

Tovias, A.: Testing factor price equalization in the EEC. JCMS: J. Common Mark. Stud. 20(4), 375-388 (1982)

Venables, A.J.: Fragmentation and multinational production. Eur. Econ. Rev. 43(4), 935-945 (1999)

Wolszczak-Derlacz, J.: Does one currency mean one price? East. Eur. Econ. 48(2), 87-114 (2010)

Wood, A.: How trade hurt unskilled workers. J. Econ. Perspect. 9(3), 57-80 (1995) 